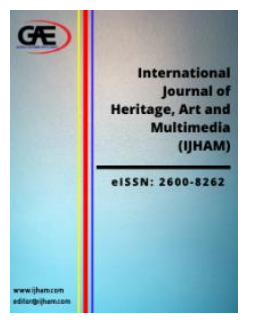

\author{
INTERNATIONAL JOURNAL OF \\ HERITAGE, ART AND MULTIMEDIA \\ (IJHAM) \\ wWw.ijham.com
}

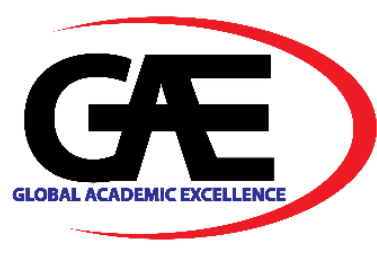

\title{
MALAYSIAN-OMANI HISTORICAL AND CULTURAL RELATIONSHIP: IN CONTEXT OF HALWA MASKAT AND BAJU MASKAT
}

Rahmah Ahmad H. Osman ${ }^{1 *}$, Md. Salleh Yaapar ${ }^{2}$, Elmira Akhmatove ${ }^{3}$, Fauziah Fathil ${ }^{4}$, Mohamad Firdaus Mansor Majdin ${ }^{5}$, Nabil Nadri ${ }^{6}$, Saleh Alzeheimi ${ }^{7}$

1 Dept. of Arabic Language and Literature, Kulliyyah of Islamic Revealed Knowledge and Human Sciences, International Islamic University Malaysia

Email: rahmahao@iium.edu.my

2 Ombudsman, University Sains Malaysia

Email: mdsalleh@usm.my

3 Dept. of History and Civilization, Kulliyyah of Islamic Revealed Knowledge and Human Sciences, International Islamic University Malaysia

Email: elmira@iium.edu.my

4 Dept. of History and Civilization, Kulliyyah of Islamic Revealed Knowledge and Human Sciences, International Islamic University Malaysia

Email: fauziahfathil@iium.edu.my

5 Dept. of History and Civilization, Kulliyyah of Islamic Revealed Knowledge and Human Sciences, International Islamic University Malaysia

Email: firdausmansor@iium.edu.my

$6 \quad$ University Sains Malaysia

Email: nabilnadri@gmail.com

7 Zakirat Oman \& Chairman of Board of Directors, Trans Gulf Information Technology, Muscat, Oman

Email: zuhimi@gmail.com

* Corresponding Author

\section{Article Info:}

\section{Article history:}

Received date:20.01.2021

Revised date: 10.02. 2021

Accepted date: 15.02 .2021

Published date: 03.03.2021

\begin{abstract}
:
The current re-emergence of global maritime activity has sparked initiative from various nations in re-examining their socio-political and cultural position of the region. Often this self-reflection would involve the digging of the deeper origin and preceding past of a nation from historical references and various cultural heritage materials. From this, realisation of the pattern in maintaining an empire or enterprise from the immediate ancestral society could be turned into a model or benchmark in developing the present and future planning of the nation. In the context of Islamic civilisation development along the IndoPacific seaboard the Omani and Malay nations are the two integral entities that had assumed their central role as seafarers, traders, rulers, and travellers in
\end{abstract}




\section{To cite this document:}

Osman, R. A. H., Yaapar, M. S., Akhmatove, E., Fathil, F., Majdin, M. F. M., Nadri, N., \& Alzehelmi, S. (2021). Malaysian-Omani Historical and Cultural Relationship: In Context of Halwa Maskat and Baju Maskat. International Journal of Heritage, Art and Multimedia, 4 (12), 17-27.

DOI: $10.35631 /$ IJHAM.412002.

This work is licensed under CC BY 4.0

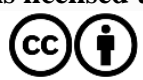

maintaining the dynamics of the region and this happened as early as the Islamic period of the 9th and 10th century CE up till 16th and 19th century when series of European colonial infiltration disrupted greatly the balance of this classical network. The Kitab at-Tarikh Silsilah Negeri Kedah, for instance, presented a vivid story of an Omani captain and his ship in the early 1700s who had met Kedahan people. The cultural heritage of the Arabian Gulf brought mainly by the Omanis could even be found there such as a fabric product known as Baju Maskat and a kind of delicacy known as Halwa Maskat which signal that the cultural hegemony of the Omanis indeed exceeded their immediate political boundary.

Keywords:

Malaysian; Omani; Historical; Cultural; Relationship

\section{Introduction}

This paper is based on a research conducted aiming to discover the significant historical references and cultural heritage regarding the Omani nation's contact with the classical past of the Malaysian nation which originated from as early as 9th and 10th century CE up till 18th and 19th century CE. It will present explicit Arabo-Persian, and Malay written accounts which related the direct and indirect contact of Omani nation with ancient Malay ports. The historicalcultural heritage of Arabian Gulf is evidently reflective in the usage of the Omani dress-style known as Baju Maskat and the Indo-Arabic cuisine, Halwa Maskat in Malaysia which this paper aims to discuss. Nevertheless, it is also important to note here that the historical-cultural relations between Oman and Malaysia in the past could also be seen through the existing maritime trading contacts that existed between the two political entities where frequent exchanges of products or goods had taken place. This is made possible given the fact that the Southeast Asian under Srivijaya enterprise became the middleman which helped distribute Chinese merchandise into the Indian Ocean.

This seafarers for sure landed in all port of calls in between to obtain foods, woods, and other needed materials and in various early Abbasid period historical records we may find their presence across the Indo-Pacific region resonating a kind of proto naturalist and anthropologist mind describing the society they saw and mingled with, on how their life looked like, their habitat and riches which to be found among their natural environments. Initial Arabic aspiration towards anything Chinese - regarded as the major and most advance civilisation in the world somehow overshadowed the role of Southeast Asian ports until 9th century when the massacre in Canton port of South China as mentioned by Idrisi in his Nuzhat al-Mustaq had more than 120000 western traders killed by the rebels and forced them to resettle at Champa, Malay Peninsula and Sumatra when from thereon no Arab or Chinese ship passed further.

For years to come they only meet in the Malayan hubs situated in the middle of the seafaring journey. In addition to the aforementioned, among the early pioneers of Omani Muslim seafarers were Abu Ubaidah Abdullah bin al-Qasim, an Ibadhi Syeikh who went to China bringing goods such as rope and sobir (a type of herb) with him shortly before 758CE rebellion. Second example would be an-Nahdhor bin Maimun of the people of Basrah. He was of Omani descent who went to China in between the end of 8th century and early 9th century CE. Several orientalist scholars also found that some of the Muslim graves in China was indeed are showing its origin from Oman and Arabian Gulf. According to al-Lawati (1994) the remains of a mosque Copyright @ GLOBAL ACADEMIC EXCELLENCE (M) SDN BHD - All rights reserved 
known as al-Dzikra could still be seen in China. This era was indeed the opening of the Arab chronicle to include their lore with experience encountered with the Malays in subsequent centuries.

Starting as late as 12th century Al-Idrisi noted that the Omani trade shifted to Aden as it proven to be a new route to cater Indian trade patronized by the Ayyubids and the Mamluks of Egypt and Syria. From the southern Arabian Ports of Marbat and Dzofar some commodities were traded to India such as the Arabian Horse in exchange of spices. The focus in the east was the disintegration of Srivijaya following the fall of Song and Abbasid and it gave way for new Islamic sultanates with Red Sea inclination to emerged. In 1260s the Sultanate of SamuderaPasai emerged while according to At-Tarikh Salasilah Negeri Kedah a century earlier in 1136 $\mathrm{CE}$ the Buddhist kings of Kedah converted to Islam by a Sufi from Baghdad. This rare reference on the Gulf area is indeed interesting and Kedah will provide to be a close-knit counterpart of the Gulf particularly of Oman from 9th century CE until the time of colonial full domination following the establishment of English settlements in Penang (1786), Province Wellesley (1800), Malacca and Singapore (1824).

Omani factor on the Malay Peninsula which will be demonstrated in the following section also had its ancient origin, where the early king of Kedah was stated in local annals to had come from the land of Rum and Gumarun, both were overlapping locality situated in the port city of Hormuz. The king was stated to come from a branch of a royal family ruling the Gulf region. Many of the Omani reference in the Malay hikayats, syairs and pantuns were mainly taken from the account of the Malays who encountered with the various mercantile products of the post Portuguese Oman from 1600s up till 1800s. for example, the reference on Oman occurred to be associated with Muscat products in the form of textile industry and edible material dubbed as 'Muskati' or 'Maskati'. This cultural material products were mentioned in the Malay hikayat the Maskati horse used in a Persianate legend called Syair Madhi depicting a hero named Badrul Jabil (Jamil) and Rauza Khan who were fighting a tyrant back in their home in Persia.

In another collection, similar story can be found in Tarikh Silsilah Negeri Kedah, the official chronicles of Kedah, in which mentioned the story of the son of the late sultan, Tengku (Tunku later sultan) Muhammad Jiwa whom for several years had embarked in a soul-seeking journey which had him arrived at the feet of a certain saintly scholar known as Syeikh Abdul Jalil alMahdani (Mahdali). For years he studied under the Syeikh from Palembang, to Java and until they settled at Malabar in southern India were eventually his heart was moved to return home. It is here that they took an Omani Baghalah (a type of vessel, also known as dhow in East Africa) which was on the way to Margi (Mergui) in southern Myanmar. The Muscati shipwright (jeragan) in such fashion had his luck to be immortalize in the history of the Malay nation as he then followed southward the returning party where the future sultan was onboard up until they reached Langkawi Island several miles off the coast of Kedah. Today, the place is known as Selat Beghalah Balek located south of Kuah in between Tanjong (Cape of) Chawat and Pulau Bumbon.

The rare occurrence of direct Omani maritime involvement per se in various Malay literature signifies that the Malays were not accustomed to meet the formers after the time their literature industry began to mature in between 17th and 20th century and thus the Omanis were left behind insignificant in the literate Malay society except in few cases as demonstrated by the 
story from At-Tarikh Silsilah Negeri Kedah and also in cultural heritage in the form of material products which will be demonstrated in the following section of this paper.

\section{The Omani Cultural Material Heritage in Malaysia}

There References on historical records are not enough to prove the whole discourse regarding the presence of Omani elements in a particular foreign setting, and often alongside textual references, cultural material and heritage studies are needed as cross-reference to strengthen or compliment the former. Some evidence comes in the form of archaeological remains which in majority remained sealed from general knowledge except via systematic excavations or deep archaeological analysis; secondly, via ethnic study where we may find several living evidences of the distant or near past where physical and material items are still at use among local society such as in the form of traditional attires, metalworks, ceramics, woodcrafts, cuisines, books, drawings, et cetera. The Omanis historical presence in Malaysia as presented in the previous section in this sense may be represented by many of those but the most obvious would be that of Baju Maskat, a type of northern Malaysian traditional attire, and secondly that of Halwa Maskat which is a traditional Malay delicacy also popular initially in northern Malaysia. However, both attested to the pre-eminence of Omani cultural material heritage in the IndoPacific region specifically in Kedah where various historical records are found in reference.

\section{Baju Maskat}

One of the most significant cultural material evidences of Omani nation in Malaysia, but less known by many would be the existence of a classical fashion top known as Baju Maskat. In Malay language throughout the Indo-Pacific region baju means a top garment worn by either men and women alike while 'Maskat' in this sense is a subject of it being Muscati in origin which has been the Omani's biggest emporium for centuries. Therefore, the cloth somehow connected with the Omani nation and it had become the symbol of Malayan nobility preference for over at least two centuries starting from the arrival of the colonial power in the late $16^{\text {th }}$ century. It is an important evidence that shows the influence of the Omani culture in the region and its presence also had a long-lasting effect especially around the sultanate of Kedah Darul Aman in northern modern Malaysia.

The problem of determining the origin of Baju Maskat (or Muskat) is that there is no mentioned on the details of how it came for the first time to the region, the matter of whom had brought it and why the local Malays particularly of Kedah Sultanate in Malaysia came to adopt it as a part of their traditional attire will remain without an exact answer due to the inexistence of precise historical record mentioning the process. However, upon future examining the material references it can be generally assumed, the Maskat cloth might have come together with a group of people most certainly traders in contact directly or indirectly from around Oman. This means that a wide array of maritime community is involved who are living in Oman proper themselves, or from those frequenting Oman but originally came from the seaboards of Yemen and Hadhramaut; the Indians of Gujarat, Malabar, and Bengal; and the Sumatrans whom were known to had also frequented the many ports of Kedah since early century of the Common Era and thus such continuous presence brought along Omani commodities to the ports of Old Kedah (Bujang and Kuala Muda) and those of New Kedah (Kuala Perlis, and Kuala Kedah) in Malaysia. 
Volume 4 Issue 12 (Mac 2021) PP. 17-27 DOI 10.35631/IJHAM.412002

The advent of early modern Kedah in between 18th and 20th century saw the rise of Kuala Muda and later Penang Island as the centre of trade items flowing in and out of the region laden to India and Arabia. As we had discussed in the previous section it is clear that following the English domination of Oman in 19th century, direct Omani communication with the Far East and Southeast Asia had dropped to almost non-existence and this was replaced by other communities taking advantage from the colonial entrepreneur network - the Hadhramis and Indians. They are the most likely candidates whom had brought many Arabian Gulf and Omani merchandises to the orient especially the saudagiris of Gujarat based in Ahmedabad and the port of Surat. This saudagiri family (saudagar or merchants in Malay, originated from Indian vocabulary) of Ahmedabad went to Siam under its first ancestor known Abdultayeb Esmaili and became the textile agent for the royal family of Siam for around two hundred years.

For years, Esmailji and his family helped regularised the movement of textiles and fulfilling the palace's demand for required types of fabrics and pattern designs where they were in constant contact with suppliers back in Gujarat. This Indo-Siamese product was known as Pha Maskat or Maskati cloth and was intended to come with highest of quality, expensive and naturally could only be owned by people from royal upbringing or those who were granted to possess it. In addition, the version of Pha Maskat or Maskati is really similar with the earlier type of Kedahan Maskat which was a loose, short and thin jacket with additional embroidery, while the much latter version in 20th century came in the form of thicker, black and embroidered jacket worn as top. The older version of Baju Maskat is related to fashion top jackets known as Baju Sikap, Baju Takwa and Baju Layang suited with Seluar Aceh (Acehnese pants), a dastar or tengkolok (two kinds of Malay headgears), a samping (waistcloth resembling the Scottish kilt), and a keris (traditional dagger), which however had its origin long before the early modern time and at least was known since the Malacca and Johore Sultanates.

With the continuous evolution of the Maskat cloth, suggest that the cloth was continuously brought to the region since the early time and the style might be different according to the time and place it had developed. It can be noted that in the later form of Baju Maskat, the cloth was heavily influence from the European official ceremonial jacket mixed with the style from Ottoman Devlet after the former arrival to the middle east. During this colonial era in middle east, the classical Turco-Arabian world started to transform themselves from wearing turban, caftan, and robes into adopting the European styled jackets, pants, crown of fez (which the Malays transformed into their black headgear known as songkok). This new style of Baju Maskat will later spread to the Malay World especially in Aceh, Siak, Banjar and Kedah and it is hard to determine its exact point of origin.

Furthermore, in early 1900s for instance the Malay sultans and society were greatly inspired by Pan-Islamism movement rooted in Middle East and by claiming their brotherhood and affiliation with the Ottoman Empire - then in gradual decline- they somehow have a mindset, or rather a false hope of living within an all-Islamic alliance which was aspired to cast away colonial rulers of their respective lands including in Malaya which terribly failed. This idea might clarify on why the early Malay especially the sultans adopted Baju Maskat as the formal attire for the royal family. However, if we compare the Baju Maskat of the Kedahan style with the traditional attire worn by many Omani sultans from Bu Sa'idi lineage since $19^{\text {th }}$ century $\mathrm{CE}$, we can see the similarity in which the bisht or long, loose, black robe, worn on top of another inner white dishdasha carries a certain special insignia of Bu Sa'idian pattern made of Copyright (C) GLOBAL ACADEMIC EXCELLENCE (M) SDN BHD - All rights reserved 
golden embroidery and it happened to be almost similar with embroidered lining found on Kedahan Baju Maskat of the later form.

Thus, it eliminated its association with any European tailorship except after the British colonization. Baju Maskat of Kedah was somehow modelled on this, and known to be made with 'pesak jubah' (robe posture) which was shortened to suit the Malaysian warm and humid climate and preference for a good ventilated attire. It looks obviously like a shortened Omani bisht reaching down to thigh worn with a pair of embroidered black trousers. An official royal programme book published by the Jabatan Penerangan Malaysia (2017) directly stated that Baju Maskat design was directly taken from Omani capital, Muscat. After the independence of Malaysia in 1957, Baju Maskat was introduced as the traditional garment of high nobility and to the office of king of Malaysia. This was done by the late First Prime Minister, Tunku Abdul Rahman Putra al-Hajj (1903-1990) who in turn was a royal prince of Kedah and the son of its late ruler, His Majesty Sultan Abdul Hamid Halim Syah (1864-1947). Because of his position as prime minister during that time, he managed to indirectly spread the ancient Kedahan culture into the central administration.

His Majesty Tuanku Syed Harun Putra ibn Syed Hassan Jamalullail (1920-2000) of the Kingdom of Perlis, which was a part of Kedah sultanate before 1842, Kedahan Baju Maskat was made as official attire of the Malaysian paramount up to this day as mentioned by the Tuanku. The attire was later worn during wedding ceremonies among distinguishes family to preserve the heritage.
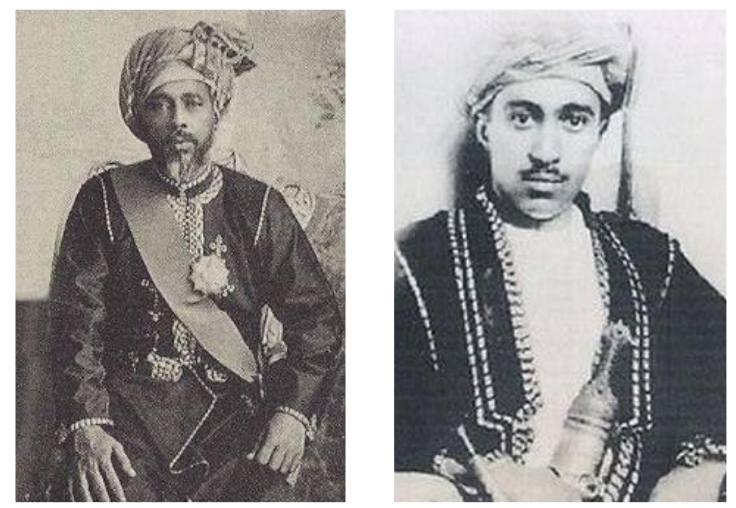

Figure 1: Images Show The Early Forms Of Royal Robe Worn By The Omani Sultans. 


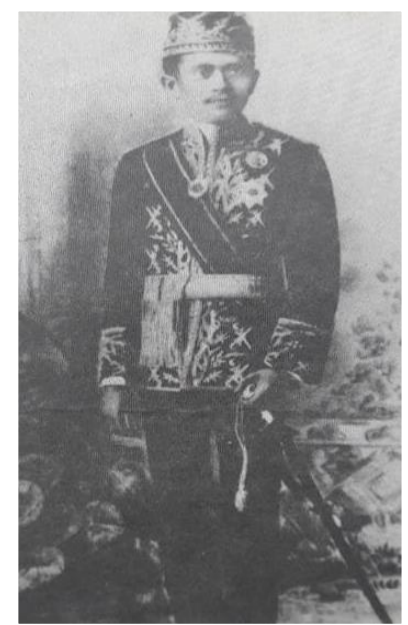

\section{Figure 2: Image Show A Type Of Baju Maskat Worn By Sultan Abdul Hamid Halim Syah Of Kedah In About 1894}

\section{Halwa Maskat}

The Omani culture as a global cultural phenomenon also had left an impressive footprint all over the world with a form of its traditional cuisine known as the halwa or sweet confection. This could be found throughout the Indo-Pacific world where Omanis maritime influence could be felt from South Africa to Japan, and even in Europe marking its popularity once tasted by all locals along the network. In Malaysia particularly and generally in the Malay World this is known as Halwa Maskat suggesting its origin from the Muscati community from the previous centuries. However still people after generations have made it as their own cultural heritage while forgetting its distant root in the Arabian Gulf which worth of rediscovery. Similar with the case of Baju Maskat, it is difficult to determine the exact date of the arrival of Halwa Maskat to Malaysia.

The cuisine was traditionally introduced by the peranakan (foreign people usually raised in Malaya, a term similar with Muwallad in the Middle East) who socio-economically and culturally were dominant in their new venture. Over time their presence also began to make inroad into adjacent sultanates, with the Hadhramis became a part of the ruling elites or bangsawan (nobility) of the Malay kingdoms of Perak, Johore, and Kelantan. However, it is also worth to note that the tradition might originated much earlier than is believed by many where Haruo Endo (2012) in his extensive work of Omani cultural presence in the Far East had noted that the Japanese had adopted a particular sweet confectionary known as aruheito which came from the Portuguese alfeloa, a form of latinized Arabic for al-Halwah (lit. sweets).

Endo believed that the aruheito was Omani in origin where it developed first into Iberian kneaded-sweet pastry before making inroad to Japan, thus explaining the rather dissimilar taste and form it possesses from the authentic al-halwa of the Omani community or any other communities which adopted the recipe. As such in Malaysia one will found that Halwa Maskat differed from a place or family with the others, distinguished from the Indians, Arabs, and Malays all who had creatively adapted the halwa with their respective tongue preference and this usually could be found in any diaspora cuisines underwent metamorphosis, but still the 
Volume 4 Issue 12 (Mac 2021) PP. 17-27 DOI 10.35631/IJHAM.412002

main recipe consists of starch, egg, water, ghee, and nuts and Omani specialty is from mixing rose water and saffron to the ingredients. Omanis also are famous for their mixing of Omani honey into their halwa turning it into an expensive product which come in different colours, white, black, and brown, and which is consumed seasonally usually in May and June while depending on dates as sweet in the others.

Halwa Maskat throughout the years became a popular delicacy which is served during big celebrations such as during Eid celebration, mawlid an-Nabi and wedding ceremony in Malaysia similarly to how the Omanis presented the cuisine during their gatherings. For example, in 2017 the royal family of Johore Sultanate presented Halwa Maskat as part of their wedding dowry's presents in which signifies that Halwa Maskat had become part of traditional Malay delicacies of the royal palaces for ages. In its own way, food can also become part of the cultural object since it can represent the identity and pride of particular people from the society.

This cultural phenomenon over food is regarded by some as a technological feat and as a substantial effect coming out of human philosophical mind and their diverse cosmology in perceiving the immediate environment.

At such, Halwa Maskat within the Malaysian society as well as the Omanis' indeed is an integral element of the people cultural dignity and represent their long civilising process in particular as the imperial and global powers controlling the riches of the Indo-Pacific region and all kind of nations passing its land and water. The cultural exchanges of the vibrant Age of Trans Indianica for the pass two millennia indeed had prospected the arrival of varieties of foreign foods onto local dining tables and helped coloured the society to be all-embracing, open-to-all and cosmopolitan in nature. Rapid globalisation and modernisation of Malaysia had given much little space for traditional heritage such as Halwa Muskat to thrive and this is considered as a great danger for the survival of the Malays and Malaysian identity. Thus, the Jabatan Warisan Negara (National Heritage Department) of Malaysia had recently tried to curb this development by listing it as a part of the endangered heritage cuisine in need of preservation.

Various activities come out from this inclusion where cultural programmes will present the halwa as a richly delicacy which worth a good reception among the large segment of the society in the future. Many recipe books and websites were created to develop awareness and promote Halwa Maskat more widely in Malaysia and for the young generations to appreciate it. Gastronomy cultural material heritage could be regarded as an important premier historical resource for societies whose past depended and lived beyond the reach of literate circle. Thus, the image of the past is visible only through the survival of cultural material heritage and it is a pity when the rare occurrence of textual records is worsened by the vanishing of cultural materials. Halwa Maskat thus is relevant to be regarded as a time capsule, recording the evolution of the Malay society and its Omani-Arabian flavour coming along with.

Wherever textual references could not be found much in describing the cultural situation we are enlightened via the many songs, lore, dances, plays, drawings, engravings, sculptures, and other artistic manufactures as the witness. Society passed down many details of their life as well in the form of their oral narration, where in this context had conveyed uncountable known 
and unknown recipes and cooking mastery techniques which produce beautiful and delicious cuisine. According to the Convention for the Safeguarding of the Intangible Cultural Heritage produced by UNESCO (2003) the preservation of intangible cultural heritage including food and other communal products is very important to the development of sustainable society. As a result, it will preserve the critical knowledge and traditional heritage that only known by people and could provide solutions to many issues being faced.
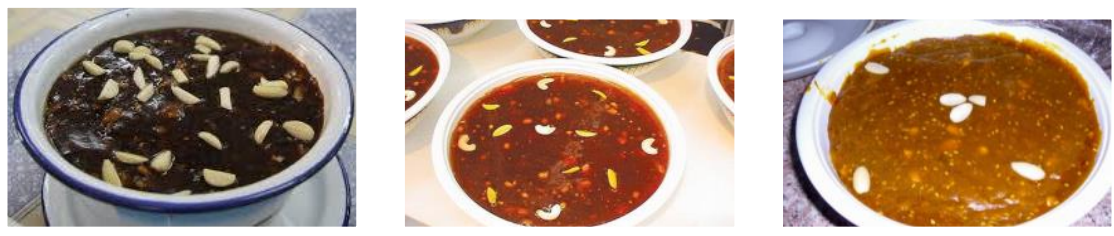

\section{Figure 3: Different Type Of Omani Halwas Which Found Their Cultural Influence All} Over The Indian Ocean Region

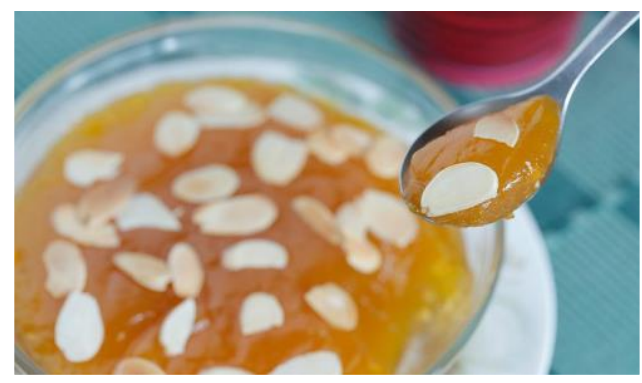

\section{Figure 4: Halwa Maskat In Malaysia Is A Prized Delicacy Due To Its Unique Taste And Tedious Preparation. It Is A Symbol Of Local Cultural Richness And Social Unity.}

\section{Conclusion}

This paper demonstrated the reality of the historical-cultural legacy of Oman (Baju Maskat and Halwa Maskat) which could be found in Malaysia. Oman indeed has a lot of common characteristic with Malaysia as vital key players of Indian Ocean maritime trade and geopolitics. The rapid process of trade activity between the two regions during the ancient times allows the cultural exchange to happened between Malaysia and Oman and the cultural heritage is still preserved until now. Academic research should practically be extended into developing cultural heritage material as the potential local economy force by promoting traditional handicraft production such as Baju Maskat and Halwa Maskat. With available information and proper planning these merchandises may be re-introduced with new varieties depending on the market demand locally and internationally, and also current disadvantages they are having may be improved with the availability of scientific skill and technology. Traditional craft industry normally becomes the natural attraction for tourist seeking exotics in countries they are visiting, and this opens to the visitors the door to a new experience resulting in mutual respect and appreciation. Craft industry development is important to revive the longlost culture or the almost extinct cultural materials or practices in a form of re-enacting the existing remains of the past. Thus, it will turn a particular cultural community into a living museum which gives real soul and spirit to material of the past in possession and exposing its Copyright $\odot$ GLOBAL ACADEMIC EXCELLENCE (M) SDN BHD - All rights reserved 
Volume 4 Issue 12 (Mac 2021) PP. 17-27 DOI 10.35631/IJHAM.412002

real significance. In many developed countries a cultural villages or towns portrayed living images of the past instead of depending solely on the concept of indoor museums.

\section{Acknowledgement}

This article is an output of our on-going FRGS19-030-0638 Project Funded By The Ministry Of Higher Education Malaysia.

\section{References}

A. Hamid, Rogayah, and Mariyam Salim. (2006). Kesultanan Melayu Kedah. Kuala Lumpur: Dewan Bahasa dan Pustaka.

Abdul Rahman Kaeh. (1997). Syair Madhi. Kuala Lumpur: Perpustakaan Negara Malaysia.

Abushouk, Ahmed Ibrahim, and Hassan Ahmed Ibrahim. (2009). The Hadhrami Diaspora In Southeast Asia: Identity Maintenance or Assimilation. Leiden: BRILL.

Ahmad Hakimi Khairuddin, and Wan Abdul Kadir Wan Yusoff. (2006). "Pengumpulan Perkataan Perkataan Untuk Kamus Sebagai Pelestarian Warisan Seni Budaya Melayu". In Persidangan Kebangsaan Antarabangsa Pengajian Melayu. Kuala Lumpur.

Ahmad Jelani Halimi. (2013). Undang-Undang Laut Melayu. Kuala Lumpur: Dewan Bahasa dan Pustaka.

Anwar et al., R. (2018). "The Development of Formal Ceremonial Coronation Attire of Seri Paduka Baginda Yang Di-Pertuan Agong And Seri Paduka Baginda Raja Permaisuri Agong from I-XIV Starting From 1957 Until 2016". In Proceedings of The Art and Design International Conference. Singapore: Springer.

Arsyad Mokhtar. (2016). Aja'ibul Hind Barrihi Wa Bahrihi Karya Buzurg Al-Ramhurmuzi. Pulau Pinang: Baytul Hikma.

Arsyad Mokhtar. (2017). Rihlatus Sirafi : Catatan Pengembaraan Di Alam Melayu, China, India Dan Afrika.. Pulau Pinang: Baytul Hikma.

Arsyad Mokhtar. (2018). Risalah Al-Ula Abu Dulaf Al-Muhalhil. Kuantan: Geroda Merah Press.

Balādhurī, Aḥmad ibn Yahyá, Max Schloessinger, and Shelomo Dov Goitein. (1936). The Ansab Al-Ashraf Of Al-Baladhuri. Jerusalem: Jerusalem U.P.

Clarence-Smith, William Gervase. (2018). Locally Produced Textiles on The Indian Ocean Periphery 1500-1850: East Africa, The Middle East, And Southeast Asia. London: SOAS, University of London.

Ding, Choo Ming. (2014). "Memory And Local Stories : Sources Of History And Knowledge". International Journal Of The Malay World And Civilisation IMAN 2 (1), 15.

Endo, Haruo. (2012). Oman And Japan Unknown Cultural Exchange Between the Two Countries. Muscat: Muscat Printing Press.

Geneva, Michelle Archambault. (1989). Blockprinted Fabrics of Gujarat For Export to Siam: AN Encounter with Mr. Maneklal T. Gajjar.

Harian, Wartawan. (2015). Halwa Maskat Semakin Dilupakan. Sinarharian.Com.My. Retrieved from http://www.sinarharian.com.my/edisi/utara/halwa-maskat-semakindilupakan-1.420682.

Jabatan Penerangan Malaysia. (2017). "Istiadat Pertabalan Ke Bawah DYMM Seri Paduka Baginda YDPA XV". Kuala Lumpur: Jabatan Penerangan Malaysia.

Jones, Russell. (1999). Hikayat Raja Pasai. Kuala Lumpur: Yayasan Karyawan \& Dewan Bahasa dan Pustaka. 
Volume 4 Issue 12 (Mac 2021) PP. 17-27 DOI 10.35631/IJHAM.412002

Joseph, Salim. (2015). Traditional Omani Halwa Passes the Test of Time. Times of Oman. Retrieved from http://www.timesofoman.com.

Kedah Dari Segi Sejarah (Terbitan Khas Pulau Langkawi). (1971). Cawangan Kedah Alor Setar: Persatuan Sejarah Malaysia.

Machado, Pedro, Sarah Fee, and Gwyn Campbell. (2018). Textile Trades, Consumer Cultures, And the Material World of The Indian Ocean: An Ocean of Cloth. USA: Palgrave Macmillian.

Manickavasagan et al., Annamalai. (2011). "Texture Profile Analysis (TPA) Of Omani Halwa While Replacing Ghee with Vegetable Oils,". Presentation, CSBE/ SCGAB. Canada, 2011.

Muhammad Hassan bin To Kerani Mohd. Arshad. (1968). Al-Tarikh Salasilah Negeri Kedah. Kuala Lumpur: Dewan Bahasa Dan Pustaka.

Posrithong, P. (2003). Artistic Relations Between Indian Textiles for Thai Market and Bencharong Ware.

Rex Smith, G. (2007). "Dionisius A. Agius, Seafaring In The Arabian Gulf And Oman: The People Of The Dhow". Journal Of Semitic Studies 52 (1), 176-177. doi:10.1093/jss/fg1060.

Rooney, Sarah. (2017). House of Maskati: One Indian Family's Siamese Textile Legacy. Singapore: Prestel

Samad Ahmad, A. (2003). Sulalatus Salatin (Sejarah Melayu). Kuala Lumpur: Dewan Bahasa dan Pustaka.

Shawal, Zubaidah. (1994). Busana Melayu. Kuala Lumpur: Jabatan Muzium dan Antikuiti Malaysia.

Siti Hawa Haji Salleh. (1998). Hikayat Merong Mahawangsa. Kuala Lumpur: UM

Warisan Kebudayaan Tidak Ketara Dan Pembangunan Mapan. (2018). Ebook. International Information and Networking Centre for Intangible Cultural Heritage in teh AsiaPAcific Region, UNESCO. Accessed August 7.

Yusoff, Omar, and Noriah Mohamed. (2010). "Daripada Jawi Peranakan Kepada Melayu: Tinjauan Terhadap Komuniti Jawi Peranakan Di Pulau Pinang Pada Abad Ke-21". SariInternational Journal of The Malay World and Civilisation 28 (2). 